Open Access

\title{
The effect of land use on slope failure and sediment generation in the Coromandel region of New Zealand following a major storm in 1995
}

Michael Marden ${ }^{1 *}$ and Donna Rowan ${ }^{2}$

\begin{abstract}
Background: Part of the Coromandel region (North Island, New Zealand) was subjected to a severe storm in March 1995. Analysis of relevant data provides a valuable opportunity to assess the type, extent, distribution and sediment generation rates by slope failures associated with steep-land forests and harvest practice.

Methods: Slope failures were mapped at 1:10 000 scale for stands of planted exotic forest, areas of exotic forest cutover, indigenous forest, indigenous secondary regrowth, and pasture. Slope failure dimensions and bulk density were used to calculate catchment-based sediment mass and generation rates by: (i) failure type, (ii) vegetation type, (iii) slope group, (iv) Land Use Capability unit (LUC), and by (v) catchment. The proportion of the total storm sediment load discharged as yield was estimated from records of flow and depth-integrated sediment samples.

Results: Storm-initiated slope failures generated $\sim 0.5 \mathrm{Mt}$ of sediment, predominantly by debris avalanche. Most were located within indigenous forest and secondary regrowth and generated $\sim 78 \%$ of the total sediment mass. Few slope failures occurred within standing exotic forest and inclusive of areas disturbed by harvesting operations (cutover) generated $\sim 21 \%$ of the mass and, $1 \%$ was derived from pastoral hill country. Sediment generation rates were greater from areas of exotic forest clearfelled three years before the storm and these were 2.5 times greater than from cutover clearfelled just before the storm. This result is explained by the progressive loss of strength from decaying tree roots that had not yet been countered by an effective root system under a new tree crop. Furthermore, rates were highest for slopes between 26 and $35^{\circ}$ and, of the 11 LUC units, were highest for units Vle11 and VIle2. For the combined Opitonui and Awaroa catchments, $24 \%$ of the storm sediment load was discharged as yield with $\sim 76 \%$ remaining as in-channel storage.
\end{abstract}

Conclusions: The erosion response was primarily controlled by rainfall variation and slope, which overrode the influence of vegetation cover. Time since clear-felling had a secondary influence. A re-evaluation of erosion susceptibility in steep-land terrain and a return to the identification, mapping and geomorphic interpretation of site-specific hazards, particularly from an operational perspective-in advance of harvesting -is recommended.

Keywords: Storm effects; Slope failures; Sediment mass and load; Geomorphic mapping

\footnotetext{
* Correspondence: mardenm@landcareresearch.co.nz

'Landcare Research, PO Box 445, Gisborne 4010, New Zealand

Full list of author information is available at the end of the article
} 


\section{Background}

Internationally, much has been written on the relationship between forest-harvesting activities and landslide initiation. Studies have varied in scope from regional inventories (Rood 1984; Sauder et al. 1987; Millard 1999), watershed and other area-limited studies (Thomson 1987; Jakob 2000) to individual landslide reports. Similarly, studies have varied in objectives from those focussed primarily on causative factors (Schwab 1983; Millard 1999) to frequency of landslide occurrence (O'Loughlin 1972; Rood 1984; Guthrie 2002), recovery (Smith et al. 1986), and terrain types identified as particularly prone to landsliding (Howes 1987; Rollerson 1992; Rollerson et al. 1998).

In New Zealand, there has been a long history of concern about mass wasting (erosion)-predominantly by landsliding-that has largely focused on 'storm-effects' in areas of highly erodible hill country in the North Island (e.g. Committee of Inquiry 1939; Taylor 1938, Taylor, NH comp 1970; Blaschke et al. 1991; Dymond et al. 2006) ${ }^{a}$. Landslides triggered by major storm events are the most widespread and destructive erosion process (Glade 1998) and yet the documentation of incidences of storm damage has been poor. Glade and Crozier (1996) and Phillips et al. (2012) commented on the issues this raises not only for identifying relationships between land use/management practices and landsliding, but also for determining temporal trends in the incidence of landsliding, and developing improved hazard and risk analysis approaches to underpin land (including forest lands) management policy and practice.

The majority of documented storm-related studies have focussed on the impacts of landslide initiation following regional and localised storm events. They have also tended to compare relative differences in landslide densities across a range of forest types-both indigenous and exotic-and drawn comparisons with adjacent areas of pasture (Phillips et al. 1990; Hicks 1991; Marden et al. 1991; Marden and Rowan 1993; Bergin et al. 1995; Fransen and Brownlie 1995; Fahey and Marden 2000; Reid and Page 2002; Fahey et al. 2003, 2004; Dymond et al. 2006) ${ }^{\mathrm{b}}$. These studies indicate a strong relationship between the incidence of landslides and land cover with fewer landslides occurring in areas of indigenous forest, and in exotic forest-once canopy closure has been attained between $\sim 5-8$ years after planting - than in areas of adjacent pastoral hill country (Selby 1967; Salter et al. 1983; Hicks 1989; Phillips et al. 1990; Marden et al. 1991; Marden and Rowan 1993; Dymond et al. 2006) ${ }^{\mathrm{a}}$. Many assessments have been produced as client-based reports or as internal file notes. These have often not been officially published so cannot be cited as references. However, such reports may contain valuable information so details of relevant ones are provided as endnotes.
Much of New Zealand's steep hill country was originally covered in indigenous forest that was cleared for pasture in the nineteenth century. Pastoral farming failed (Poole 1960; Olsen 1970), in part, due to erosion. Attempts to reduce erosion have largely been through reforestation with the establishment of exotic plantations (Taylor, 1970; McKelvey 1992; Marden 2004, 2012; Phillips and Marden 2005) ${ }^{c, d}$. Of the current exotic forest estate, thirty-three per cent ( 0.6 million hectares) is located on steep hill country ${ }^{\mathrm{e}}$. Most of this was originally planted as watershed protection/production forests with a soil conservation role and for most of the rotation such forests provide a high level of slope stability. Many are located in regions where climate is predicted to become dominated by long dry spells but with more frequent high intensity storms ${ }^{\mathrm{f}}$, including those in Northland, Coromandel, Bay of Plenty, Taranaki, Gisborne-East Cape, Nelson and Marlborough ${ }^{\mathrm{g}}$. Within these regions, significant areas of forest have reached, or are nearing, maturity so harvesting is on the increase.

Landslides do occur in planted forests ${ }^{\mathrm{h}, \mathrm{i}, \mathrm{j}}$ but tend to be most extensive on slopes recently clearfelled following harvesting. The predominant planted tree species is Pinus radiata D.Don, for which a 30-year period between planting and harvest is common in New Zealand (McLaren 1993). Within planted forests, storm-initiated debris avalanches and soil slip failures are the main sources of sediment and woody debris entering stream channels-often resulting in major debris flows ${ }^{k}$. Their occurrence between 1994 and 1998 was more common in Northland, Auckland, Coromandel, Eastern Bay of Plenty, and Nelson-Marlborough, with fewer occurrences in the central North Island, East Coast, and Hawke's Bay ${ }^{k}$. In the last five years, however, there has been a high frequency of events, not only in the Bay of Plenty, ${ }^{\mathrm{l}, \mathrm{m}}$, Nelson $^{\mathrm{n}, \mathrm{o}}$, and Marlborough ${ }^{\mathrm{p}}$ but also in the East Coast in 2002 and 2011 and Hawke's Bay in 2011 (Phillips et al. 2012). In all these regions, storms producing more than $80 \mathrm{~mm}$ of rain in 24 hours usually lead to the saturation of shallow hill soils resulting in landslides (Crozier and Eyles 1980; Caine 1980).

Internationally and locally, it is widely accepted that forest harvesting accelerates sediment production, particularly during storm events. Often this increase is associated with road construction and subsequent roadrelated and landing failure (Mosley 1980; Pearce and Hodgkiss 1987; Fahey and Coker 1989, 1992; Beverley et al. 2001; Megahan et al. 1991, 2001). The susceptibility of forest cutover to storm-initiated mass wasting (predominantly landslides) has similarly been well documented (Bishop and Stevens 1964; Ziemer 1981a, b, c; Furbish and Rice 1983; Guthrie 2002; Marden et al.

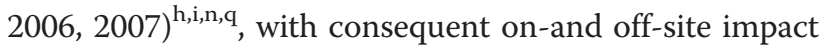
following a storm often exacerbated by the presence of 
logging slash (woody debris) ${ }^{\mathrm{e}, \mathrm{k}}$. Large areas of exotic forest are approaching maturity. These are due to be harvested within the next decade, which will result in an increase in clearfelled land susceptible to erosion. There is also a high probability that the frequency of severe weather events will increase in the future due to climate change. The combination of these factors means that it is highly likely that erosion will occur in forested areas in the future.

There have been numerous reports of off-site impacts downstream of areas of exotic planted forest following high intensity storm cells in recent years (Horner 2012) $^{\mathrm{i}, \mathrm{j}, \mathrm{i}, \mathrm{o}}$ although not always coincident with harvesting. Several reports have specifically implicated forest cutover as a significant source of sediment delivered to stream channels in regions considered environmentally sensitive (and therefore susceptible to human-induced disturbances) (Basher et al. 2011; Horner 2012) $)^{\mathrm{i}, \mathrm{q}}$. Previous research has suggested that areas of cutover are at greatest risk and will remain susceptible to the impact of storms until the replacement trees attain canopy closure at $\sim 8$-years after establishment (Phillips et al. 1990; Marden et al. 1991; Marden and Rowan 1993) ${ }^{\mathrm{r}}$. Surprisingly, however, only rarely has sediment production (either as a consequence of storminitiated landsliding (Dymond et al. 2006) ( $^{\mathrm{a}, \mathrm{h}}$ or by other processes such as slope-wash erosion (Marden et al. 2006, 2007) been quantified for areas of exotic forest cutover.

Such reports place pressure on the forest industry to review their current harvesting and post-harvest practices to lessen the off-site impacts associated with future storm events ${ }^{\mathrm{e}, \mathrm{o}}$. The introduction of the Resource Management Act in 1991 has also made forest management more challenging due to its emphasis on avoiding, mitigating and remedying adverse 'effects' on the environment. Thus, harvest- and post-harvest-related impacts on steep and erodible hill country must be balanced against stewardship of the land (Marden and Saunders 1992). It is difficult to assess the potential for landslide initiation and to devise/evaluate appropriate counter measures due to the unpredictability of storm events and a paucity of quantitative data on storm-related impacts of exotic forest harvesting over its short history, particularly for areas of cutover.

This paper presents a retrospective assessment of sediment generated by slope failures following a single storm in March 1995. The distribution of slope failures, mass and rate of sediment generation are evaluated for indigenous and exotic forest, over a range of slopes and for specific areas of land. This study provides much needed process-based quantitative data on sediment generation from New Zealand's forested areas, particularly cutover, during such events.

\section{Background on study area and environs Location}

The Whangapoua forest study area (Figure 1) is located on the eastern side of the Coromandel Peninsula within the Thames-Coromandel District. The steeper parts of this peninsula form the Coromandel Range, of which the uppermost slopes constitute part of the Coromandel Forest Park. Here, the vegetation is predominantly indigenous forest.

From its highest point near Castle Rock (521 m above sea level), this part of the Coromandel Range is deeply incised by short, steep streams-the Awaroa, Opitonui, Owera, Weiti, Waiatekatanga, and several minor streams-that have a high incidence of flood flows and the potential to deliver significant volumes of sediment to Whangapoua Harbour and Mercury Bay Estuary (Figure 1).

\section{History of use}

Whangapoua forest $(10,500$ hectares) spans the midslope reaches of the Awaroa, Opitonui, Owera and Weiti streams. This forest was planted between 1949 and 1985, predominantly with exotic Pinus radiata. Substantial areas of secondary indigenous vegetation were permitted to regenerate on steep banks (riparian) adjacent to stream channels following scrub clearance (by root raking and roller crushing). Pastoral farming is currently restricted to rolling hill country located in the lowermost parts of these catchments and to the coastal floodplain.

A storm in 1972 initiated shallow landslides that, in turn, caused significant sedimentation on farmland located downstream of this forest. This storm coincided with the early establishment phase of Whangapoua Forest and raised a number of issues of concern to residents, regional authorities, recreationists, and the forest owners well before harvesting began. These included the likelihood of impacts resulting from on-site forestry activities (road and landing construction, harvesting, logging traffic) and their potential off-site effects, particularly on streams and associated estuaries and harbours ${ }^{\mathrm{s}}$. These harbours are noted habitats for estuarine birds and shellfish while the surrounding sea is internationally renowned for its game fishing. In addition, the Coromandel area is a popular tourist destination for both land and sea-based recreation.

Upgrading of the forest's road infrastructure began in 1991 and harvesting began in 1992. By 1995, 6\% of Whangapoua Forest had been harvested ( $~ 8 \%$ of the area assessed for post-storm damage). Cutover areas were aerially desiccated before replanting then oversown with a mix of introduced grasses (Yorkshire fog, Holcus lanatus; Punawai browntop, Agrostis capillaris) (Wardle 1991), and legumes (White clover, Trifolium repens; Birdsfoot trefoil, Lotus angustissimus) (Roy et al. 1998) to minimise surface erosion, predominantly by slope-wash, during the postharvest period. Aerial spraying with herbicides has been 


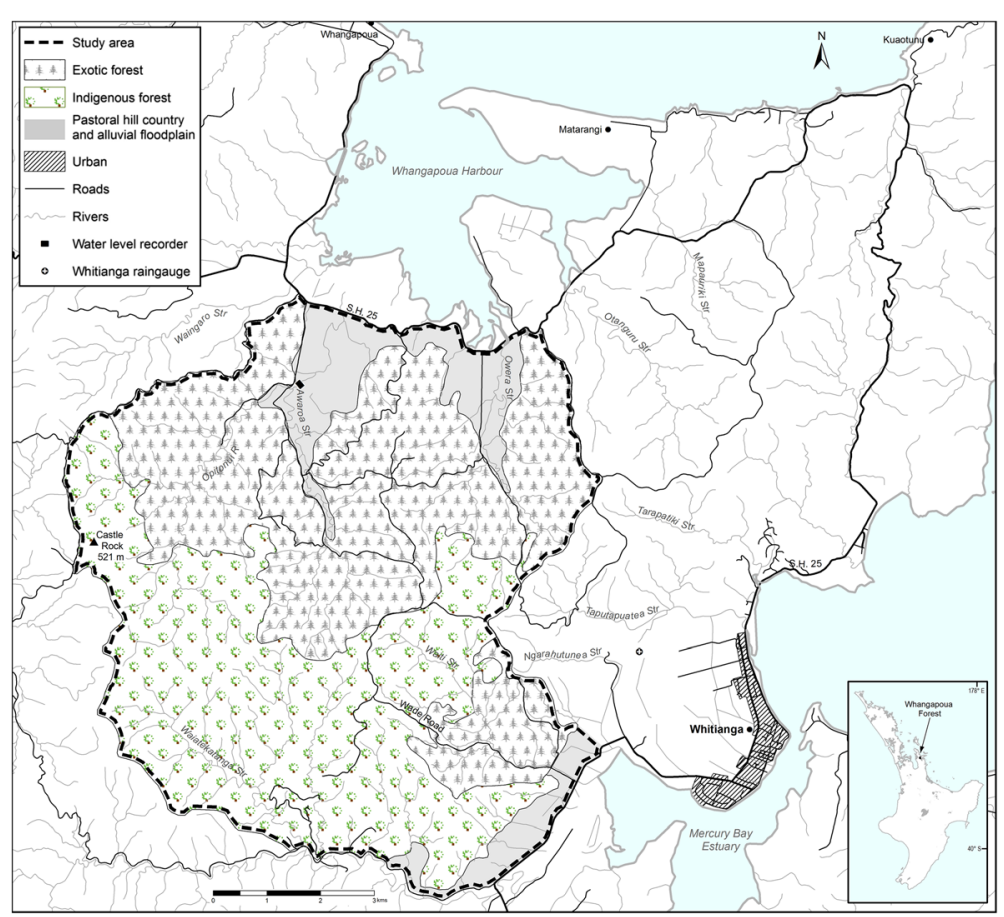

Figure 1 Location map of the Whangapoua forest study area showing the distribution of indigenous and exotic forest, pastoral hill country and floodplain, catchment boundaries, and location of rain gauges and water level recording site.

used to control competition from regenerating indigenous and wilding exotic pines.

\section{Geology}

The basement geology of the area consists of hydrothermally altered Whangapoua and Matarangi andesites of Miocene age (Skinner 1976). Soils are highly variable, with soil types being strongly related to parent materials, elevation and slope steepness. They have developed from deeply weathered andesite. Steep land soils, including Aroha (As) and Te Kie (Tks), occur in steep to very steep terrain in the uppermost parts of the major river catchments where exposed bluffs of weathered andesite are common. At lower elevations, on moderately steep to steep terrain, Waitakere and Rangiuru hill soils predominate (McCraw and Bell 1975); that is, Typic Orthic Brown Soils and Mottled Orthic Brown Soils (Hewitt 2010), respectively. Soils on easy to rolling terrain include Whitianga Silt loam and Waitekere Clay loam (McCraw and Bell 1975).

The weathered nature and high clay content of these soils predispose slopes to shallow, rapid slides (soil slip and debris avalanche) and flows involving soil and regolith. Soil slips typically have a small scar $\leq 1 \mathrm{~m}$ deep exposing a slip surface with debris being redeposited as a narrow debris tail downslope of the scar. A debris avalanche is a similar type of failure but tends to be larger, the scar is deeper $(2-5 \mathrm{~m})$ and, hence the depositional debris tail tends to occupy a significant length of the slope (Eyles 1985).

\section{Climate}

Though temperate, the climate at Whangapoua is known for its frequent, high-intensity localised storms, often of tropical origin that frequently result in severe flooding. The average annual rainfall is $1729 \mathrm{~mm}$, with a distinct March to June 'wet season's . The estimated 2-year return period rainfall is $127-133 \mathrm{~mm}$ in 24 hours (New Zealand Meteorological Service 1980). One of the largest storms in recent years occurred on 3rd March 1995. Visual inspection of landslide damage, rainfall, and stream flow data together suggest that the March 1995 storm encompassed an area of approximately $40 \mathrm{~km}^{2} \mathrm{~h}$. Rainfall records at Castle Rock, located in the headwaters of the Opitonui catchment, show that the duration of this storm was $\sim 24$-hours. During this period $94 \mathrm{~mm}$ of rainfall was recorded (1.3-year return period), half fell within a 2-hour period at an intensity of $25 \mathrm{~mm}$ /hour while the maximum hourly rainfall intensity reached $37 \mathrm{~mm} /$ hour (return period 1.8 years) ${ }^{\mathrm{t}}$ (from Table 1). However, eastward of this location, rainfall data collected at an automatic weather station located near Whitianga (Figure 1) showed that the 6-hour total of $112 \mathrm{~mm}$ (return period 8.4 years), and a 24-hour period total of $154 \mathrm{~mm}$ (return period of 3-years) was considerably greater than that recorded at Castle Rock. As the Whitianga rain gauge 
only records 6-hourly totals (Table 1 ) it is not possible to estimate return periods, based on rainfall intensities, for the early part of the storm and where local reports suggest that much of the rain fell within a less than 6-hour period, and likely centred over the most severely impacted Awaroa, Owera and Weiti catchments. Although storm-based, stream water-level records from a site located downstream of the Opitonui and Awaroa confluence (Figure 1), provide valuable insights into the impact of this storm they do not reflect the contrasting flow response between these two streams. For example, poststorm observations of their channel form and fauna indicate that flows in the Opitonui Stream had minimal impact on the in-stream habitat and macro invertebrate population whereas the flow response in the Awaroa Stream had considerable impact. Further east in the Owera and Weiti Streams the impact was extreme, and from the limited river flow data available from the Owera Stream, it is likely the channel was affected by debris flow(s ${ }^{\mathrm{u}}$. A 24-hr rainfall intensity of $12.8 \mathrm{~mm} \mathrm{hr}^{-1}$ (which translates to an annual return period of 30-40 years (High Intensity Rainfall Design System HIRDS)) was recorded at the Whitianga rainfall gauge. This value equates well with the estimated return period of flow from the Owera Stream of between 20 and 50 years as reported by Quinn et $\mathrm{al}^{\mathrm{v}}$.

\section{Methods}

The study area (6,984 ha) includes Weiti, Opitonui, Awaroa, Owera, Waiatekatanga, and a number of smaller catchments (Figure 1). The first four catchments incorporate a range of land uses including indigenous and exotic forest, secondary indigenous regrowth, exotic forest cutover, and pastoral hill country. Predominantly indigenous forest, the Waiatekatanga and several smaller catchments are here collectively referred to as 'miscellaneous' catchments (Table 2).

\section{Mapping}

Landslides (debris avalanche and soil slip), locations of stream bank collapse (the result of bank undercutting during flood flows), and landing (a cleared area to which logs are hauled for sorting) failures were identified by stereoscopic analysis of 1:10,000 scale colour photographs taken within days of the March 1995 storm. Whole-catchment aerial photographic coverage was available for all but $\sim 2 \mathrm{~km}^{2}$ of the upper reaches of the Opitonui and Waiatekatanga catchments.

Each erosion feature was delineated on photographic prints using a fine mapping pen, assigned a unique number, and the failure type (debris avalanche, soil slip, stream bank collapse or landing failure) was noted. The first three types are considered as natural phenomena while the latter is associated with harvesting activities. Using an epidiascope to adjust for minor differences in scale, mapped areas were then transferred from the photographs onto a base map. A 1:10,000 scale base map was created from a 1:25,000 scale topo plot (New Zealand Map Series 270, part Sheet T 11) to match the scale of both the aerial photographs, and the forest compartment maps. The latter were geo-referenced to the New Zealand Map Grid 1949 projection.

A number of problems were encountered with the aerial photography, including:

(a) photographic prints were of variable contrast and exposure

(b)shadow obscured landslides located in the steeper, dissected, and more heavily vegetated areas, and within areas of secondary indigenous regrowth along steep-sided riparian stream banks

(c) low-altitude photography in very steep terrain produced considerable relief distortion.

These were countered by mapping landslides located within the central part of each photographic print. The

Table 1 Maximum rainfall intensities, totals and return periods recorded during the March 1995 storm

\begin{tabular}{|c|c|c|c|c|}
\hline \multirow{2}{*}{$\begin{array}{l}\text { Maximum rainfall } \\
\text { intensities and total rainfall }\end{array}$} & \multicolumn{2}{|l|}{ Castle Rock } & \multicolumn{2}{|l|}{ Whitianga } \\
\hline & Rainfall (mm) & Return period (years) & Rainfall (mm) & Return period (years) \\
\hline Max 10 minute intensity & 15.5 & 1.8 & & \\
\hline Max 20 minute intensity & 25 & 2.4 & & \\
\hline Max 30 minute intensity & 31 & 2.5 & & \\
\hline Max 1 hour intensity & 37 & 1.8 & & \\
\hline Max 2 hour intensity & 52 & 1.8 & & \\
\hline Max 3 hour intensity & 57 & 1.7 & & \\
\hline Max 6 hour intensity & 65.5 & 1.4 & 112 & 8.4 \\
\hline Max 12 hour intensity & 83.5 & 1.4 & & \\
\hline Max 24 hour intensity & 94 & 1.3 & 154 & 3 \\
\hline Total rainfall over period & 96 & & 154 & \\
\hline
\end{tabular}

Source: Williams ${ }^{\mathrm{t}}$. 
Table 2 Details of slope failure number and per cent by area (ha) for each of the classification types used to define the study area

\begin{tabular}{|c|c|c|c|c|c|}
\hline \multirow[t]{2}{*}{ Classification } & \multicolumn{2}{|c|}{ Area assessed } & \multicolumn{2}{|c|}{ Slope failures } & \multirow[t]{2}{*}{ Failures per hectare } \\
\hline & ha & $\%$ & Number & $\%$ & \\
\hline \multicolumn{6}{|l|}{ Land use } \\
\hline Exotic Forest & 2139 & 30.6 & 36 & 4 & 0.02 \\
\hline Indigenous Forest & 2684 & 38.4 & 394 & 42 & 0.15 \\
\hline Secondary Indigenous Regrowth & 859 & 12.3 & 210 & 23 & 0.24 \\
\hline Exotic Cutover 1992/93 & 115 & 1.6 & 86 & 9 & 0.75 \\
\hline Exotic Cutover 1993/94 & 213 & 3.1 & 109 & 12 & 0.51 \\
\hline Exotic Cutover 1994/95 & 263 & 3.8 & 83 & 9 & 0.32 \\
\hline Pasture (hill country) & 375 & 5.4 & 13 & 1 & 0.03 \\
\hline Pasture (floodplain) & 336 & 4.8 & 0 & 0 & 0 \\
\hline TOTAL & 6984 & 100 & 931 & 100 & \\
\hline \multicolumn{6}{|l|}{ Slope Group } \\
\hline$A\left(0-3^{\circ}\right)$ & 306.5 & 4.4 & 0 & 0 & 0 \\
\hline $\mathrm{D}\left(16-20^{\circ}\right)$ & 361.6 & 5.2 & 9 & 1 & 0.02 \\
\hline$E\left(21-25^{\circ}\right)$ & 1623.3 & 23.2 & 239 & 25.5 & 0.15 \\
\hline$F\left(26-35^{\circ}\right)$ & 4493.9 & 64.3 & 679 & 73 & 0.15 \\
\hline$G\left(>35^{\circ}\right)$ & 198.7 & 2.9 & 4 & 0.5 & 0.02 \\
\hline TOTAL & 6984 & 100 & 931 & 100 & \\
\hline \multicolumn{6}{|l|}{ LUC unit } \\
\hline Ils & 306.5 & 4.4 & 0 & 0 & 0 \\
\hline Ille & 183.1 & 2.6 & 0 & 0 & 0 \\
\hline Vle2 & 148.8 & 2.1 & 2 & 0.2 & 0 \\
\hline Vle3 & 212.8 & 3.0 & 7 & 0.8 & 0.03 \\
\hline Vle8 & 465.9 & 6.7 & 36 & 3.9 & 0.08 \\
\hline Vle10 & 1403.7 & 20.1 & 123 & 13.2 & 0.09 \\
\hline Vle11 & 2071.1 & 29.7 & 478 & 51.3 & 0.23 \\
\hline VIle2 & 1882.7 & 27.0 & 264 & 28.4 & 0.14 \\
\hline VIle7 & 110.7 & 1.6 & 17 & 1.8 & 0.15 \\
\hline VIle8 & 191.8 & 2.7 & 4 & 0.4 & 0.02 \\
\hline VIle9 & 6.9 & 0.1 & 0 & 0 & 0 \\
\hline TOTAL & 6984 & 100 & 931 & 100 & \\
\hline \multicolumn{6}{|l|}{ Catchment } \\
\hline Opitonui & 1538 & 22.0 & 83 & 9 & 0.05 \\
\hline Awaroa & 1168 & 16.7 & 94 & 10 & 0.08 \\
\hline Owera & 1365 & 19.6 & 402 & 43 & 0.29 \\
\hline Weiti & 910 & 13.0 & 160 & 17 & 0.18 \\
\hline Miscellaneous & 2003 & 28.7 & 192 & 21 & 0.09 \\
\hline TOTAL & 6984 & 100 & 931 & 100 & \\
\hline
\end{tabular}

$\sim 60 \%$ overlap provided by each print allowed all landslides to be captured with minimal distortion. Mapped landslides were then transferred to the base map.

In addition, numerous check marks (e.g., fences, stream edges, tracks, roads, quarries, trigonometric survey points) identified on the aerial photography were also present on both the base map and the forest compartment maps. These provided useful geo-referenced points with which to register the location of mapped landslides and thus were instrumental in minimising any 
spatial distortion (unquantified) that may have incurred during the transfer of erosion features from the photographs, and their registration to the base map.

For financial reasons, spatial data were not captured in geographic information system (GIS) at the time of mapping. Instead, a digital planimeter was used to measure the spatial extent and number of slope failures in each of eight vegetation types (exotic forest, indigenous forest, secondary indigenous regrowth, exotic cutover 1992/93, cutover 1993/94, cutover 1994/95, pasture (hill country) and pasture (floodplain) assessed from the forest compartment maps (Table 2). The study area and number of slope failures were also classified into five slope groups: A $\left(0-3^{\circ}\right) ; \mathrm{D}\left(16-20^{\circ}\right) ; \mathrm{E}\left(21-25^{\circ}\right) ; \mathrm{F}\left(26-35^{\circ}\right)$; and G $\left(>35^{\circ}\right)$, and into separate LUC units (IIs, IIIe, VIe2, VIe3, VIe8, VIe10, VIe11, VIIe2, VIIe7, VIIe8, and VIIe9) from the New Zealand Land Resource Inventory Worksheets (1975) (Table 2). The distribution of slope failures, by catchment, is presented in Table 2. Details of each LUC unit are provided in Additional file 1. The distribution of exotic and indigenous forest relative to slope group is presented in Table 3.

\section{Sediment mass calculations}

The eroded area (i.e. the source zone from which sediment was derived) was measured using a dot grid for each of the four failure types and this was termed 'scar'. For the larger slope failure types (debris avalanche and landing failure) the 'scar' and the depositional material extending downslope from the source area (termed 'debris tail') were measured separately. In May 1995, the dimensions (length, width and depth) of scars and debris tails for a variety of sizes of each of the failure types were measured in the field. This verified that for debris avalanche and landing failures their source area (scar) made up about one third of the total mapped eroded area (scar plus debris tail). Therefore a 'scar to debris tail' ratio of 1:3 was used along with a mean depth of $3 \mathrm{~m}$ for debris avalanches and $1.04 \mathrm{~m}$ for landing failures (scar areas only) to calculate sediment mass. For soil slips, the small size of the scar and minimal run-out distances on the gentler topography (i.e. limited development of a debris tail) precluded the mapping of areas of scar and debris tail separately. Scar depths approximate depths reported following an earlier storm (Salter

Table 3 Distribution (percentage) of standing exotic and indigenous forest relative to slope group

\begin{tabular}{lll}
\hline Slope group & Exotic forest & Indigenous forest \\
\hline$D\left(16-20^{\circ}\right)$ & 8 & 0 \\
$E\left(21-25^{\circ}\right)$ & 40 & 20 \\
$F\left(26-35^{\circ}\right)$ & 49 & 60 \\
$G\left(>35^{\circ}\right)$ & 3 & 20 \\
\hline
\end{tabular}

et al. 1983). Consequently, sediment mass (Table 4) was calculated using the total measured area and a mean depth of $1.0 \mathrm{~m}$. Similarly, sediment mass for stream bank failures is based on the measured eroded area (bank length times height) and a mean bank retreat distance of $0.86 \mathrm{~m}$. Mass ( $\mathrm{t}$ ) (Additional files 2-5) was derived using a mean bulk density of $1.2 \pm 0.11 \mathrm{t} \mathrm{m}^{3}$ from 10 samples of weathered andesitic parent material dried for 24 hours at $105^{\circ} \mathrm{C}$ and weighed as described in Marden et al. (2006).

The density of the four slope failure types combined, relative to vegetation cover, slope group and LUC unit, is presented in Table 2.

\section{Contribution to stream sediment yield}

An assessment of the relative contribution of sediment delivered to stream channels is based on the connectivity of each mapped feature to a watercourse. An erosion feature with a debris tail that reached a watercourse was recorded as 'connected' and likely contributed to stream sediment load. A subsequent Coromandel-based study determined that for landslides (debris avalanche and soil slips) initiated during storms in 1991 and 1992, and assessed as being 'connected' to a stream channel, approximately half the material generated at the time of failure was delivered to the stream and half was retained on slope (Marden et al. 2006). Based on this approach, a sediment delivery ratio (SDR) of 0.5 for storm initiated debris avalanche and soil slips was adopted and applied also to landing failures on similarly steep slopes. It was assumed that all the material derived from failures located on riparian stream banks entered the channel so this was assigned a SDR of 1.0. Using these criteria, the relative proportion of sediment mass delivered to streams as sediment load was assessed. Source area (ha), sediment mass $(\mathrm{t})$, sediment generation rates $\left(\mathrm{t} \mathrm{ha} \mathrm{h}^{-1}\right.$ of scar area), and the mass ( $t$ ) delivered to stream channels, are presented in Table 4.

Sediment generation rates and the annual sediment yield (primarily from the March 1995 storm) were compared with the longer term (1992-2004) record of flow and depth-integrated sediment samples collected from a permanent water level and sediment sampling site located on the Opitonui Stream downstream of the Opitonui/ Awaroa confluence (Figure 1). For the March 1995 storm, the suspended sediment yield was calculated by summing the product of suspended sediment concentration and flow over the duration of the storm ${ }^{\mathrm{w}}$.

\section{Results and Discussion}

\section{The March 1995 storm}

The relative sediment generation rates $\left(\mathrm{t} \mathrm{ha}^{-1}\right)$ were quantified by process (Figure 2; see also Additional files $2-5$ ), by vegetation type (Figure 3; Additional file 2), by 
Table 4 Scar area, sediment mass and generation rate, sediment load and assumed sediment delivery ratio for each of the four slope failure types

\begin{tabular}{|c|c|c|c|c|c|}
\hline \multirow[t]{2}{*}{ Characteristic } & \multicolumn{4}{|l|}{ Failure type } & \multirow[t]{2}{*}{ Total } \\
\hline & Debris avalanche & Soil slip & Stream bank collapse & Landing failure & \\
\hline Total scar area (ha) & 9.9 & 11.6 & 0.3 & 0.2 & 22.0 \\
\hline Total scar area (\%) & 45.0 & 53.0 & 1.0 & 1.0 & 100.0 \\
\hline Sediment mass generated (Mt) & 0.36 & 0.14 & 0.003 & 0.003 & 0.56 \\
\hline Total sediment mass generated (\%) & 71.1 & 27.8 & 0.6 & 0.5 & 100 \\
\hline Sediment generation rate $\left(\mathrm{t} \mathrm{ha}^{-1}\right)$ & 51 & 20 & 0.5 & 0.3 & 71.8 \\
\hline Scar area (ha) with connection to stream & 9 & 5.9 & 0.3 & 0.07 & 15.3 \\
\hline Assumed sediment delivery ratio (SDR) & 0.5 & 0.5 & 1.0 & 0.5 & \\
\hline Mass delivered as sediment load (Mt) & 0.18 & 0.07 & 0.003 & 0.001 & 0.254 \\
\hline Total mass delivered as load (\%) & 71 & 28 & 0.7 & 0.3 & 100 \\
\hline
\end{tabular}

slope groupings (Figure 4; Additional file 3), by Land Use Capability unit (LUC) (Additional file 4), and for groupings of the four major catchments (Figure 5; Additional file 5).

In the Coromandel area, the return period for high intensity rainfall events is estimated to be only 2 years (New Zealand Meteorological Service 1980). However, comparison of the March 1995 storm that produced daily rainfalls in excess of $100 \mathrm{~mm}^{\mathrm{t}}$ with previous storms in this area (Coulter and Hessell 1980), and with calculated discharges (using slope area flow) suggests that its recurrence interval was in the range of 20-50 years ${ }^{\mathrm{v}}$. Between 1995 and 1998, there were other storms but none seem to have been as intense and localised or produced as high peak discharges ${ }^{\mathrm{x}}$. In contrast, there were at least six storms between 1998 and 2013 where the maximum daily discharge exceeded the 180 cumecs of the March 1995 storm. Of note is the initiation of numerous slips throughout Whangapoua Forest during the largest storm recorded over the past 21 years (31 May 2000) when discharge measured at the Opitonui site reached 218 cumecs $^{\mathrm{y}}$.

The March 1995 storm is considered atypical of the more frequent storms that characterise the Coromandel climate but is characteristic of high intensity rainstorms recorded elsewhere throughout New Zealand within the last three decades. Some assessment of resultant landslide damage, has been made for some of these storms although the results are largely qualitative (Basher et al. 2011) $)^{\mathrm{i}, \mathrm{m}, \mathrm{n}, \mathrm{z}}$.

Caine (1980) suggested a general threshold for shallow landslide failure on undisturbed slopes in terms of rainfall intensity and duration and, in terms of hourly rainfall intensities, equates to $25 \mathrm{~mm} \mathrm{hr}^{-1}$. Hourly rainfall intensities at Whangapoua during the March 1995 storm exceeded this threshold with half $(52 \mathrm{~mm})$ of the total storm rainfall $(96 \mathrm{~mm})$ occurring within a 2 -hour period (i.e. $26 \mathrm{~mm} /$ hour), and the recording of a 1-hour maximum rainfall intensity of $37 \mathrm{~mm}^{\mathrm{t}}$ (Table 1 ). This storm initiated 931 new erosion features which included 441 debris avalanches, 451 soil slips, 27 stream bank failures and 12 landing failures. The combined area of failed sites was $\sim 42$ ha $(0.6 \%$ of the study area) of which $\sim 22$ ha was identified as scar (the location of individual failures), and $\sim 20$ ha as debris tail (depositional areas predominantly associated with debris avalanche and landing failures). Of the $\sim 22$ ha scar area, soil slips comprised $\sim 11.6$ ha, debris avalanches $\sim 9.9$ ha, stream bank failures $\sim 0.3 \mathrm{ha}$, and landing failures $\sim 0.2$ ha (Table 4 ).

Collectively, slope failures generated $\sim 0.5 \mathrm{Mt}$ of sediment at a rate of $\sim 72 \mathrm{t} \mathrm{ha}^{-1}$ (Table 4). Debris avalanches generated $\sim 71 \%\left(\sim 51 \mathrm{t} \mathrm{ha}^{-1}\right)$ of this sediment, more than twice the rate generated by soil slips $\sim 28 \%\left(\sim 20 \mathrm{t} \mathrm{ha}^{-1}\right)$, and which was an order of magnitude greater than was

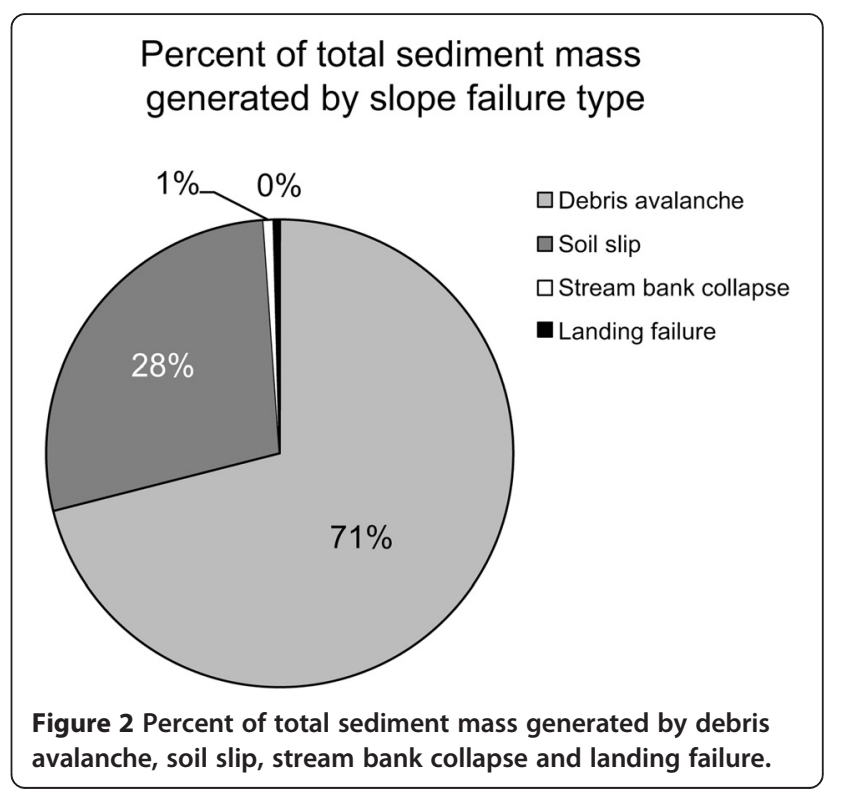




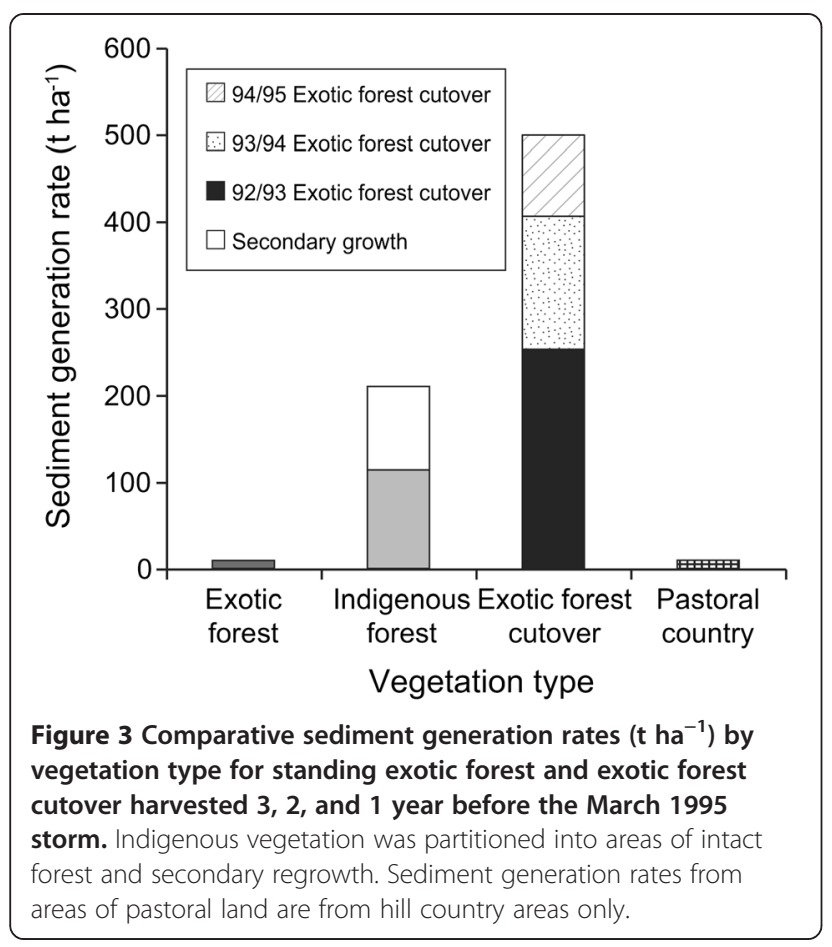

generated either by stream bank $\sim 0.6 \%\left(\sim 0.5 \mathrm{t} \mathrm{ha}^{-1}\right)$ or landing failures $\sim 0.5 \%\left(\sim 0.3 \mathrm{t} \mathrm{ha}^{-1}\right)$ (Table 4, Figure 2$)$.

Approximately $38 \%$ of the study area was covered with indigenous forest (Table 2) primarily located in the uppermost and steepest parts of each of the study catchments. Here, $80 \%$ of the indigenous forest area coincides with slopes $>26^{\circ}$ (Table 3). The majority of slope failures (73.5\%) were associated with this slope group (Table 2), thus most (42\%) were coincidental with areas of indigenous forest predominantly in the Awaroa, Owera and Weiti catchments where rainfall amount and intensity is

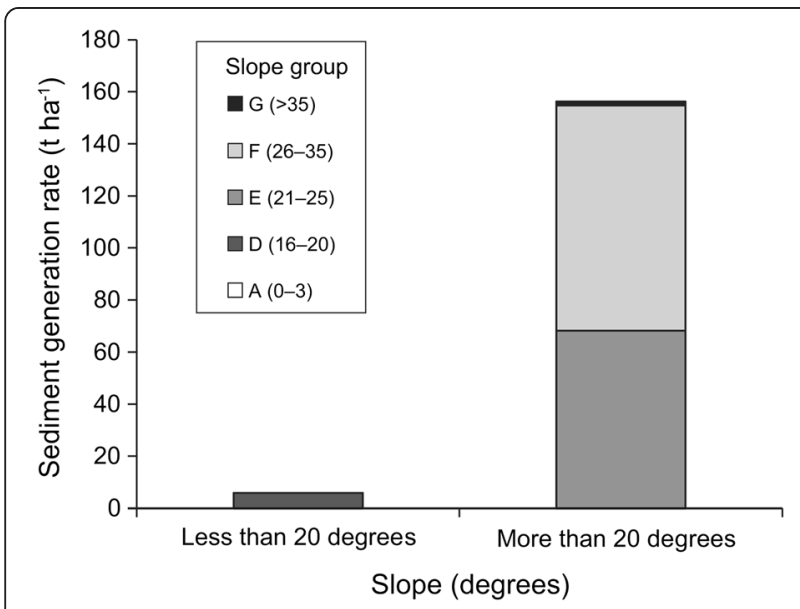

Figure 4 Contrasting sediment generation rates $\left(\mathrm{t} \mathrm{ha}^{-1}\right)$ by all processes combined, for slopes less than and greater than 20 degrees.

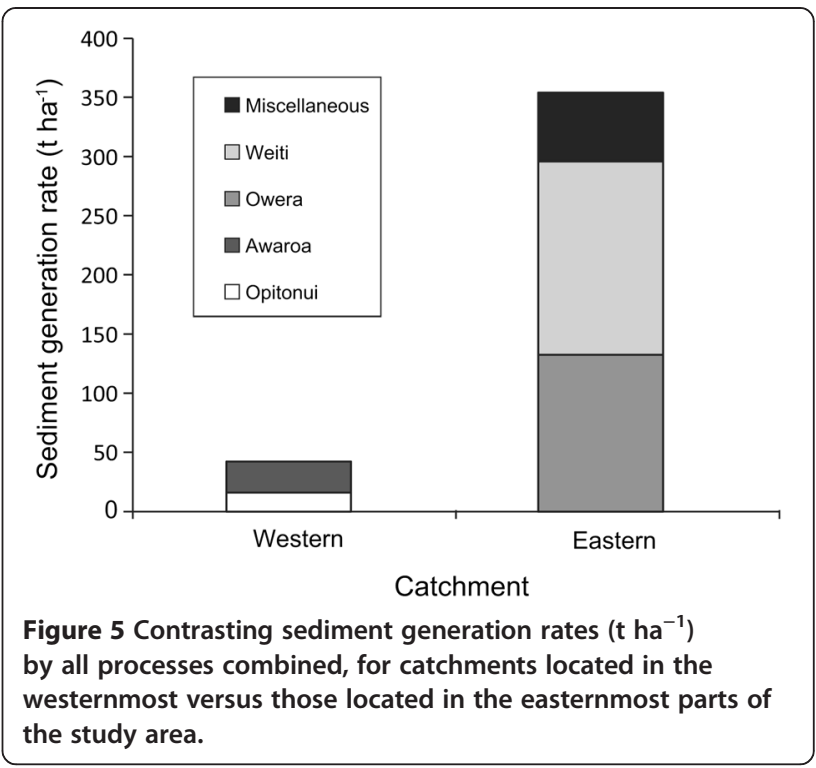

considered to have been significantly greater than for other parts (e.g. Opitonui and miscellaneous catchments) of the study area ${ }^{t}$. Here, slope failures were predominately the deeper and larger debris avalanches and collectively they generated the greatest proportion ( $61 \%)$ of the total sediment mass at a rate of $\sim 114 \mathrm{t} \mathrm{ha}^{-1}$ (Additional file 2). The density of slope failures $\left(0.15 \mathrm{ha}^{-1}\right)$ (Table 2), was similar (0.14 slips ha $\left.{ }^{-1}\right)$ to that recorded for forested areas located in the Thames-Te Aroha area following a storm on 11-13th April 1981 with a recurrence interval of 15-20 years (Salter et al. 1983), suggesting that the March 1995 Whangapoua storm was indeed a severe event.

While the cutting of trees does not increase sediment generation per se, the effects of the removal of the vegetation cover (i.e. a reduction in evapotranspiration, loss of tree root strength) generally increases the vulnerability of cutover to landslide initiation, and ultimately results in increased sediment yield (Phillips et al. 2005, Basher et al. 2011). At Whangapoua, the harvesting of exotic forest undoubtedly contributed to a significant increase in slope failures on cutover compared with mature forest. Thirty per cent (278) of all failures initiated during the March 1995 storm were on cutover, which covered only $\sim 8 \%$ of the study area (Table 2 ) while just $4 \%$ (36) occurred on land covered in standing exotic forest, which accounted for nearly $32 \%$ of the study area. Of the slope failures on cutover, only 12 were associated with forest landings while the remainder occurred on natural slopes (data not shown). The incidence of slope failure was highest $\left(0.75 \mathrm{ha}^{-1}\right)$ on cutover harvested earliest 1992/93 (<2\% of study area). Debris avalanches predominated in this vegetation type and resulted in a sediment generation rate $\sim 2.5$ times higher $\left(254 \mathrm{t} \mathrm{ha}^{-1}\right)$ 
than that generated from cutover clearfelled in 1994/95 $(<4 \%$ of study area), just before the storm (Figure 3 ). Here, the incidence of slope failures was less than half $\left(0.32 \mathrm{ha}^{-1}\right)$ that of the earlier cutover and generated just $93.8 \mathrm{t} \mathrm{ha}^{-1}$ with approximately equal contributions from both debris avalanches and soil slips (Additional file 2). This finding is consistent with that found after a storm in the Marlborough Sounds in July 1983 (O'Loughlin 1985). This result is explained by the progressive loss of strength from decaying roots that had not yet been counteracted by the development of an effective root system under the new tree crop. The root systems of Pinus radiata decay after harvesting, losing half their strength within 15-months. After 3 years, the large $(>5 \mathrm{~cm}$ diameter) structural roots are in an advanced state of decay (Watson 1990). Thus, areas of exotic forest harvested in 1992/93 would have been at their most susceptible to the initiation of the deeper and larger debris avalanches at the time of the 1995 storm. Such areas have been shown to remain susceptible to storm damage for $\geq 6-8$ years after replanting and until adequate root-soil reinforcement by the replacement trees has been re-established (Watson et al. 1995, 1999). The incidence of landslides decreases markedly after this time (Marden and Rowan 1993; Hicks 1989; Phillips et al. 1990; Marden et al. 1991) ${ }^{\mathrm{r}}$.

Slope failure densities were minimal within areas of pasture $\left(<0.03 \mathrm{ha}^{-1}\right)$ and mature exotic forest $\left(0.02 \mathrm{ha}^{-1}\right)$ (Table 2).

Fifty-two per cent of the mature exotic forest was on slopes $>26^{\circ}$ (Table 3) yet generated just $\sim 4 \%$ of the total mass at a rate of $\sim 9.5 \mathrm{t} \mathrm{ha}^{-1}$. This was the lowest of all vegetation types except pasture (Figure 3). O'Loughlin and Ziemer (1982) found that total root biomass and tree root morphology, consisting of overlapping and intertwining root systems, appear to be the major tree root variables that influence slope stability and sediment production the most. Under a mature 25-year-old pine forest, total root biomass would likely approximate 100 tonnes per hectare (O'Loughlin 1985) with extensive lateral roots spreading to $\sim 10 \mathrm{~m}$ from the stump and an average depth of $2.4 \mathrm{~m}$ (Watson 1990). Conversely, the root systems of indigenous tree species generally consist of a well-developed but surficial lateral root network, confined largely to the top $50-60 \mathrm{~cm}$ of soil and, a weakly developed vertical root system (Phillips and Watson 1994). Based on a $25 \%$ measured fraction of aboveground biomass across all New Zealand indigenous forests, the total root biomass of these forests was estimated at be $\sim 76 \mathrm{t} \mathrm{ha}^{-1}$ (Holdaway et al. 2013), i.e. $60 \%$ of the value for mature pine forest. Therefore, indigenous forests are likely to impart a less substantial contribution to slope stability, particularly during severe storm events when pore-water pressure is greatest.
The majority ( $99 \%)$ of slope failures were initiated on slopes $>20^{\circ}$ of which $73 \%$ occurred on slopes $26-35^{\circ}(\sim 64 \%$ of study area) at a density of $0.15 \mathrm{ha}^{-1}$ (Table 2). Slope failures in this slope group collectively generated $\sim 77 \%$ of the total sediment mass (Additional file 3) at a rate of $\sim 86 \mathrm{t} \mathrm{ha}^{-1}$ (Figure 4). Previous slope-stability studies in other parts of New Zealand have shown that soils on slopes over $30^{\circ}$ become unstable as they approach saturation if they do not have substantial reinforcement from competent root systems (O'Loughlin et al. 1982; Rogers and Selby 1980; Crozier and Eyles 1980). However, landslides were less frequent $\left(0.02 \mathrm{ha}^{-1}\right)$ on slopes $>35^{\circ}$ degrees ( $\sim 3 \%$ of study area), and generated only $\sim 0.05 \%$ of the total sediment mass at a rate of $\sim 1.5 \mathrm{t} \mathrm{ha}^{-1}$ (Figure 4, Additional file 3). The initiation of slope failures on the steeper slopes was limited because much of the soil and colluvium had been stripped during previous storm events $^{\mathrm{h}}$. No slope failures were recorded on slopes $<16^{\circ}$ (Additional file 3) ( $4 \%$ of study area) (Table 2 ).

Of the 11 LUC units that occurred in the study area, slope failures were densest $\left(0.23 \mathrm{ha}^{-1}\right)$ for unit VIe11 (Table 2) with a correspondingly high sediment generation rate of $\sim 100 \mathrm{t} \mathrm{ha}^{-1}$ (Additional file 4). The LUC units were defined using the New Zealand Land Resource Inventory Worksheets of 1975, i.e. 20 years before the March 1995 storm. Debris avalanche failure had not been identified in the mid-1970s as a significant erosion process associated with this unit (Additional file 1) and yet debris avalanches alone generated $\sim 71 \%$ of the total sediment mass (from Additional file 4). The potential for the current 'moderate' erosion severity to increase to 'severe' was however acknowledged but only for sheet, wind and soil slip (National Water and Soil Conservation Organisation 1975). In fact, the density of slope failures on VIIe2 identified as prone to severe debris avalanches was half $\left(0.14 \mathrm{ha}^{-1}\right)$ that on VIe11 $\left(0.23 \mathrm{ha}^{-1}\right)$ (Table 2) yet both units actually generated about the same mass (at an equivalent rate of $\sim 100 \mathrm{t} \mathrm{ha}^{-1}$; Additional file 4). Slope failures from these two LUC units combined represented approximately $57 \%$ of the study area but generated $\sim 80 \%$ of the total sediment mass (Additional file 4). Conversely, no debris avalanches were initiated on either VIIe8 or VIIe9 although both are recorded as being susceptible to severe debris avalanche failure with the potential to become very severe. In fact, only minor soil slip occurred on VIIe8 (Additional file 4).

These apparent inconsistencies in land classification highlight the difficulty of not only predicting the mode of failure on different units but also, as in the case of the March 1995 storm, of predicting the potential magnitude of the erosion response to a severe event. The variability in storm characteristics (particularly rainfall intensity and duration) associated with different storms 
also adds another level of complexity. Importantly, the results of this and previous assessments of storm damage in this region raise concerns for all areas that are currently or are likely to experience severe storm events in the future. In particular, the susceptibility of forested slopes between 26 and $31^{\circ}$ to debris avalanche failures has likely been underestimated. Also, perhaps Class VIe11 has been misidentified and should be Class VII. Furthermore, there is potential for debris avalanche(s) initiated in indigenous and exotic forests to transform into debris flow, which will pose a significant risk to the environs downstream of forests. Therefore, the current erosion potential classification likely warrants re-evaluating.

As a consequence of the March 1995 storm event, debris avalanche and soil slip failure of natural slopes along with stream bank erosion collectively generated $>99 \%$ of the total sediment mass and contributed $>99 \%$ of the $\sim 0.25 \mathrm{Mt}$ delivered to stream channels as sediment load (Table 4). Conversely, landing failures generated $<0.5 \%$ of the total sediment mass and delivered $<0.5 \%$ to the stream sediment load. Only four of the 12 landing failures contributed sediment to the stream network. Half the resulting sediment (and any associated woody debris) mobilised by them-was redistributed downslope of the point of failure and the other half remained on-slope as a depositional debris tail.

Most of the hill country in the Coromandel region is susceptible to storm-initiated landsliding. In the event of a major storm coinciding with areas of indigenous forest little can be done to prevent landslide initiation particularly as slope failures are typically the deeperseated debris avalanches that tend to generate the bulk of sediment. Within exotic forests, however, the risk of landslide damage could be alleviated by identifying the 'most-at-risk' areas and consider their exclusion from commercial forest use. As an example, Pearce and $\mathrm{O}^{\prime}$ Loughlin $^{\text {aa }}$ suggested retiring slopes $>35^{\circ}$ in the Coromandel Region from productive uses and allowing reversion to indigenous forest. In support of this, the highest frequency of shallow landsliding initiated during a storm on 14-16 March 1985 in the northern Hawke's Bay was on slopes $38-40^{\circ}$, that is, predominantly Class VII land (Harmsworth et al. 1987). More recently, Page et al. ${ }^{\circ}$ identified $30-45^{\circ}$ slopes in the Nelson region as having the highest susceptibility to landsliding following forest harvesting. That said, most of New Zealand's exotic forest estate is likely located on Class VI land, and on slopes in the range $21-35^{\circ}$. As identified in this paper, and previously by Salter et al. (1983), it is these slopes that are potentially of 'highest risk' to the initiation of landslides and potentially a significant source of landslide-generated sediment. Proposed management options for the 'most-at- risk' slopes have generally included: (i) scheduling the harvesting of the most at risk sites to periods of the year when storm events are least likely; (ii) limiting the size of harvest areas and spatially separating cutover so that areas clearfelled in successive years are not contiguous $\mathrm{s}^{\mathrm{s}}$, and (iii) increasing the planting density to reduce the period that cutover is most susceptible to storm damage (Phillips et al. 2012).

Riparian areas have also been promoted as an effective means of reducing the delivery of sediment to streams (Quinn et al. 1993). Where ground-cover vegetation has remained intact after harvesting, slope-washtransported sediment may be effectively filtered out with only a minimal amount reaching the stream network (Marden et al. 2006, 2007). However, a comparison of the rate of sediment generated by landslides and by slope-wash erosion on forest cutover, and of their relative contribution to the stream sediment load during a 2-year post-harvest period showed that: (i) the delivery of sediment to the stream network by either slope-wash erosion or landslides is highly dependent on the coupling of their respective source areas to the stream network; (ii) slope-wash erosion is the least significant of these erosion processes by several orders of magnitude (Marden et al. 2006) - a finding similar to that from a related study undertaken on cutover located in the central North Island (Marden et al. 2007); and (iii) episodic, storm-initiated landslides are the single most important sediment-generating process, providing the primary mechanism for mobilising and delivering most sediment to the stream network. The latter finding was most evident during the March 1995 storm when $\sim 91 \%$ of debris avalanches and $\sim 51 \%$ of soil slips (cf. $40 \%$ of landslides initiated during the 1113th April Thames-Te Aroha storm in 1981 reported in Salter et al. 1983, and 50\% at Otoi during a storm on 14-16 March of 1985 reported by Harmsworth et al. 1987) tracked sediment and debris through standing forest and into stream channels ${ }^{\mathrm{h}}$. Furthermore, storms commonly initiate slope failures within riparian areas and these can potentially contribute significant sediment and woody debris to the stream network. For example, soil slips were prevalent $\left(0.24 \mathrm{ha}^{-1}\right)$ in areas of secondary indigenous regrowth ( $12 \%$ of study area) at Whangapoua, which were primarily located along stream banks (riparian), and collectively generated $\sim 17 \%$ of the total sediment mass at $\sim 97 \mathrm{t} \mathrm{ha}^{-1}$ (Figure 3). Here, the absence of large trees with an extensive network of lateral roots likely increased the susceptibility of riparian slopes to the initiation of soil slips and bank undercutting during peak discharge with much of the sediment entering stream channels ${ }^{\mathrm{h}}$. Nonetheless, it is evident that the existence of riparian areas does serve to reduce the incidence of slope failures that would otherwise have occurred in the absence of a 
woody vegetation cover and that the trapping efficiency of riparian vegetation is significant in the interval between storm events.

\section{Sediment delivery and yield}

Of the 931 documented slope failures initiated during this storm, $91 \%$ of debris avalanches, $51 \%$ of soil slips, $33 \%$ of landing failures, and $100 \%$ of stream bank failures contributed sediment directly to a permanent watercourse. Of the $0.25 \mathrm{Mt}$ delivered to stream channels as sediment load (Table 4), $99.5 \%$ was derived from landslides initiated on natural slopes, while $<0.5 \%$ originated from failures associated with harvesting landings. Seventy-eight percent of the total sediment load was derived from slope failures initiated within areas of indigenous vegetation (standing forest and secondary indigenous regrowth), $\sim 21 \%$ from within standing and cutover exotic forest, and $<1 \%$ from pastoral hill country (from Additional file 2).

For the two westernmost catchments, landslide number and sediment generation rates within the Opitonui (0.05 ha $\mathrm{ha}^{-1} ; 26 \mathrm{t} \mathrm{ha}^{-1}$ ) and Awaroa (0.08 ha ${ }^{-1} ; 16 \mathrm{t} \mathrm{ha}^{-1}$ ) catchments (Table 2 \& Additional file 5) were an order of magnitude less than in the easternmost Owera $\left(0.29 \mathrm{ha}^{-1}\right.$; $\left.\sim 132 \mathrm{t} \mathrm{ha}^{-1}\right)$ and Weiti catchments $\left(0.18 \mathrm{ha}^{-1} ; \sim 163 \mathrm{t} \mathrm{ha}^{-1}\right)$ as was that within the collective of miscellaneous catchments (0.09 ha $\mathrm{ha}^{-1}, 58 \mathrm{t} \mathrm{ha}^{-1}$ ) (Figure 5; Additional file 5). In both the westernmost catchments debris avalanche and soil slip failures generated similar amounts of sediment mass whereas in each of the easternmost catchments debris avalanche failures generated 2 to 4 times more mass than did soil slips (Additional file 5).Thus landslide distribution, the type of failure, and sediment generation rates and yield suggest that the March 1995 storm had its greatest impact on the easternmost catchments where rainfall intensity and amount was likely greater than in the westernmost catchment thereby suggesting a strong relationship with rainfall.

The combined Opitonui and Awaroa catchments (2900 ha) (Figure 1) experienced a period of relatively benign suspended sediment discharge flows in the three years before the March 1995 storm. Peak flow during this period was less than $50 \mathrm{~m}^{3} \mathrm{~s}^{-1}$, which was lower than in all years since the March 1995 storm $^{\mathrm{w}}$. The average annual yield for 1995 was estimated at $6758 \mathrm{t}\left(\sim 2.3 \mathrm{t} \mathrm{ha}^{-1}\right)$, and largely derived during the March storm ${ }^{\mathrm{w}}$. Using a sediment delivery ratio of 0.5 only for the connected landslide and landing failures and 1.0 for stream bank failures, the sediment load delivered to these streams during the 1995 storm was estimated for the Opitonui at $\sim 12,331 \mathrm{t}\left(\sim 8.0 \mathrm{t} \mathrm{ha}^{-1}\right)$ and for the Awaroa at $\sim 15,516 \mathrm{t}\left(\sim 13 \mathrm{t} \mathrm{ha}^{-1}\right)$ (from Additional file 5). Approximately $24 \%\left(6758 \mathrm{t} ; \sim 2.3 \mathrm{t} \mathrm{ha}^{-1}\right)$ of the combined sediment load of $27,847 \mathrm{t}\left(\sim 9.6 \mathrm{t} \mathrm{ha}^{-1}\right)$ delivered to these streams during the March 1995 storm, was discharged as yield. This result implies that $\sim 76 \%$ of the load remained as temporary in-channel storage. This high storage component likely reflects: (i) the capacity of stream channels upstream of the gauging site to store sediment behind debris dams, within in-filled pools, and widened reaches of both the Opitonui and Awaroa streams, and (ii) the relatively low peak storm discharge of $\sim 0.04 .0 \mathrm{~m}^{3} \mathrm{~s}^{-1} \mathrm{ha}^{-1 \mathrm{u}}$. However, for every year following1995 through to 2004, the annual sediment loads at the Opitonui gauging site exceeded the pre-1995 load and reflect the probable reworking of stored bedload. Elevated yields following storms have also been observed in the Orewa catchment ${ }^{\mathrm{u}}$ and the Motueka River (Hicks and Basher 2008). Additionally, as less than $\sim 0.5 \%$ of these catchments had been harvested before the storm, slope failures on cutover would have contributed little to either the sediment load or yield at the time of this storm.

By contrast, the annual sediment yield was likely significantly greater for the Owera and Weiti catchments because: (i) rainfall intensities and totals was highest, (ii) $>30 \%$ of the total sediment load generated during the March 1995 storm was delivered to each of these streams (from Additional file 5), and (iii) severe peak specific storm discharges were estimated to be 10-times greater (0.34$0.69 \mathrm{~m}^{3} \mathrm{~s}^{-1} \mathrm{ha}^{-1}$ ) for the Owera catchment than those recorded at the Opitonui site ${ }^{\mathrm{v}}$. This resulted in substantial changes in channel morphology, sediment deposition and composition $^{\mathrm{u}}$, and also to the macro invertebrate population suggesting that the slope-area gauging may have been affected by a debris flow. Additionally, harvesting had yet to begin in the Weiti catchment while a significant proportion of the total sediment load within Owera catchment was likely derived from cutover since $~ 30 \%$ of the catchment area had been harvested before the March 1995 storm.

While most storm damage assessments demonstrate a higher incidence of slope failures associated with pastoral hill country than with forested areas, the results of this study show the reverse. This suggests that rolling hill country in pastoral use ( $\sim 5 \%$ of the study area) was peripheral to the storm centre with rainfall intensities below the $25 \mathrm{~mm} /$ hour threshold required to trigger shallow landslides (Caine 1980). Here, slope failures were minimal $\left(0.03 \mathrm{ha}^{-1}\right)$ (Table 2) and, generated $\sim 1 \%$ of the total sediment mass at a rate of $\sim 9.6 \mathrm{t} \mathrm{ha}^{-1}$ (Additional file 2).

\section{Implications for the future}

'Climate Change 2014: Impacts, Adaptation and Vulnerability' (IPCC 2014) reveals that the effects of climate change on New Zealand are likely to be more frequent floods, storms, landslides, and droughts. The country already appears to be experiencing more floods with consequent storm-initiated landsliding, and in many instances such events are coincident with areas of exotic 
forests. Each forest has its own unique set of physical characteristics (e.g. geology, slope, elevation, soils), a different mix of vegetation types at varying stages of maturity, and as each is located in a different geographical region the probabilities of storm frequency and associated rainfall intensity will be different, as will the geomorphic response and resultant aftermath. In the case of a planted forest, the extent of harvesting at the time of a storm will be critical. Furthermore, retrospective assessments of storm damage in many of the more highly erodible forested areas suggest that historical factors (physical or policy) may also have contributed, at least in part, to an increase in resultant damage-often a legacy of land clearance and stock retention policies for marginal land introduced between 1979-82 (Chudleigh et al., 1983), inherited forest infrastructure ${ }^{\mathrm{m}}$, declining health of steep land indigenous forests as a result of preEuropean fires (Esler 1963), burning and grazing (Cunningham and Stribling 1978), increased storminess (Grant 1977), and the influence of introduced animals (James 1973) (remnants of which remain within catchments re-established as exotic forest), and inadequate due diligence on a landscape's susceptibility to forest disturbance (Marden et al., 2015).

To date, the standard response following a significant storm has been to undertake a post-storm damage assessment. Most assessments are produced as client-based reports or as internal file notes and few such reports are made public. Many such assessments are merely a cursory documentation, often non-quantitative, of the extent and type of slope failure. Some may include an assessment of possible causative factors as related to geology, vegetation maturity, planting density, slope angle and, storm-related factors such as rainfall intensity, amount, and duration of the event. However, similar studies need to be conducted across many more physiographic and climatic regions to provide more transparent information on the relationships between factors that contribute to landslide occurrence within planted forests. These also need to focus particularly on areas established in first-rotation exotic forest. To be of any value, the information collected must be standardised, quantitative, and in a format for analyses and interpretation of results to be comparable. If not, the information will have little value in supporting or modifying current practices aimed at reducing the likelihood of landslide occurrence ${ }^{\mathrm{e}}$.

Previously, a number of approaches (including terrain mapping, terrain stability mapping, and terrain assessments) have been credited with reducing the risk of landslide occurrence through improved forest practices on steep, potentially unstable terrain (Fannin et al. 2005). In New Zealand, such maps were produced both for existing forests and for areas designated for future planting as 'conservation forests' (essentially for erosion- control purposes) in geologically unstable terrain. The aim was to forearm harvest planners with knowledge on the relative stability of different parts of the landscape, and on the dominant slope failure process, and to signal potential difficulties likely to be encountered during roading and harvesting. Production of these maps was shelved at the time of the New Zealand Forest Service restructuring (Phillips et al. 1989) and the subsequent sale of the State's exotic forests. As a consequence, these maps were initially underutilised by the new owners of these former state-owned 'conservation' forests, and their real value was never fully appreciated until much later when difficulties with maintaining road infrastructure arose. Interestingly, Pearce (1977) commented that a landscape zoning scheme like this needed to be developed urgently for all New Zealand plantation forests if it was to provide landslide hazard information at the planning stage of forest activities and at a scale suitable for use at the operational level-35 years later recent erosion events suggest the need remains ${ }^{\mathrm{e}}$. With the advent of new technology (LiDAR, GIS, slope-stability tools), used in combination with stereoscopic analysis of aerial photography that pre-dates planting, it is possible to anticipate with reasonable certainty the type and location of geomorphic responses during and following major storm events. Access to such information would forewarn harvest planners with the knowledge required to design a harvest strategy that avoids, or is at least cognisant of, the most vulnerable areas at times of greatest risk from the impact of storms.

The challenge ahead lies in managing New Zealand's exotic forests within environments where storms and landslide failures are a regular occurrence and where the failure of 'natural' slopes beyond the forest boundary is more often than not the greatest contributor to stream sediment load and yield. Thus the identification and avoidance of unstable terrain, especially in those forests located in areas recognised as being geologically fragile, are critical to reducing environmental, social, and economic costs incurred by slope failures that may occur at any stage throughout a forest's rotation. Although the knowledge gained from retrospective assessments of storm-related impacts is unlikely to help prevent slope failures during future storms, lessons learned will nonetheless assist in the identification of areas elsewhere where a similar potential for slope failure associated with forest activities-not just harvesting-exists. In addition, lessons learned have value in either underpinning or re-evaluating existing best management practices and environmental standards.

\section{Conclusions}

The extent and severity of landslide damage sustained across the study area during the March 1995 storm was 
consistent with a severe event with a likely recurrence interval of several decades.

The factors that most influenced differences in the extent and type of slope failure (and ultimately, in the severity of the resultant on- and off-site damage) were rainfall distribution and intensity, slope, and vegetation. Though based on limited rainfall, stream water level and sediment yield data, the general consensus is that this storm had its greatest impact where rainfall intensities and totals were highest. Additionally, high peak stream water levels and sediment yield data, together with a poststorm documentation of the distribution of slope failures (this paper), observations of channel characteristic, and impact assessments of in-stream fauna and the macro invertebrate population further substantiate that the March 1995 storm had its greatest impact within the Awaroa, Owera and Weiti catchments and, to a lesser degree, in the Opitonui and miscellaneous catchments.

The highest proportion (>99\%) of the sediment load delivered to streams was generated by the failure of natural slopes (e.g. debris avalanche, soil slip and stream bank collapse) while failures associated with forest harvesting (e.g. landing failures) contributed $<0.5 \%$.

The clearfelling of exotic forest undoubtedly increased the susceptibility of cutover to storm-initiated slope failure, predominantly from the earliest and thus the most vulnerable of the cutover areas where the progressive loss of strength from decaying roots had not yet been counteracted by the development of an effective root system under the new tree crop.

While woody debris and sediment derived from forest cutover contributed to the resultant damage sustained on floodplain areas located downstream of Whangapoua Forest, it was exacerbated by the severity and extent of landslide-generated debris derived primarily from within areas of indigenous forest located upstream of the exotic forest estate. This finding is contrary to public opinion at the time of the storm.

Also, contrary to the findings of most storm damagevegetation assessments, least sediment mass was generated from areas of pastoral hill country suggesting they lay at the outer edge of this storms influence and that rainfall intensity and totals were below the threshold required to initiate slope failure.

The initiation of landslides in steep-land forests during storms is inevitable, and valuable lessons can be learned from such events. In keeping with previous post-storm assessments of slope failure, the 'storm effect' at Whangapoua was highly variable because landslide occurrence and type were determined by specific combinations of topography, storm characteristics, vegetation cover, and in the case of areas of plantation forest, the extent of harvesting at the time of the March 1995 storm.

\section{Recommendations}

The findings of this study suggest that there is a need to reassess the erosion potential/susceptibility of steep land LUC units. Moreover, a return to terrain stability assessments based on the identification, mapping, and geomorphic interpretation of site-specific hazards, particularly from an operational perspective-in advance of harvesting-is recommended. Such maps would either support or identify the need to modify current practices aimed at reducing the likelihood of landslide (both shallow and deep-seated) occurrence and the consequent on- and off-site impacts of future storms, thereby permitting foresters to look forward toward prevention rather than backward toward correction.

\section{Endnotes}

${ }^{\mathrm{a}}$ Hancox, GT, Wright, K. (2005). Analysis of landsliding caused by the February 2004 rainstorms in the Wanganui-Manawatu hill country, southern North Island, New Zealand. (GNS Report 2005/11). Wellington, New Zealand: Institute of Geological \& Nuclear Sciences Limited.

${ }^{\mathrm{b}}$ Fransen, PJB. (1998). Slips and sedimentation in mature plantation forest and pastoral hill country, Hawke's Bay, New Zealand. (LIRO Report PR 73). Rotorua, New Zealand: Liro Forestry Solutions.

${ }^{\mathrm{c} B a y f i e l d, ~ M A, ~ M e i s t e r, ~ A D . ~(1998) . ~ E a s t ~ C o a s t ~ F o r-~}$ estry Project Review. (Report to Ministry of Agriculture and Forestry). Wellington, New Zealand.

${ }^{\mathrm{d}}$ Bayfield, MA, Meister, AD. (2005). East Coast Forestry Project Review. (Report to Ministry of Agriculture and Forestry). Wellington, New Zealand.

${ }^{\mathrm{e}}$ Amishev D, Basher L, Phillips C, Hill S, Marden M, Bloomberg M, Moore J. (2013). New forest management approaches to steep hills (MPI Technical Paper No: 2014/39 Prepared by Scion). Rotorua, New Zealand: Scion.

${ }^{\mathrm{f}}$ Gray, W, Ibbitt, R, Turner, R, Duncan, M, Hollis, M. (2005). A methodology to assess the impacts of climate change on flood risk in New Zealand. (NIWA Client Report CHC2005-060). Christchurch, New Zealand: National Institute of Water and Atmospheric Research.

${ }^{\mathrm{g}}$ Bloomberg M, Davies T, Visser R, Morgenroth J 2011. Erosion Susceptibility Classification and Analysis of Erosion Risks for Plantation Forestry. (Report for the Ministry for the Environment by University of Canterbury). Christchurch, New Zealand.

${ }^{\mathrm{h}}$ Marden, M, Rowan, D. (1995). Assessment of Storm Damage to Whangapoua Forest and its Immediate Environs Following the Storm of March 1995. (Landcare Research Contract Report LC9495/172). Lincoln, New Zealand: Landcare Research New Zealand Limited.

ijelinek, L. (2010). The Tapawera-Baton 16th of May 2010 flood-a review of erosion mechanisms, resulting 
damage and learnings from forest operations planning. (Report for Nelson Forests). Nelson, New Zealand.

${ }^{j}$ Page, MJ. (2013). Landslide and debris flows caused by the 15-17 June 2013 rain storm in the MarahauMotueka area, and the fatal landslide at Otuwhero Inlet. (Geological Sciences Report 2013/44). Wellington, New Zealand: Institute of Geological \& Nuclear Sciences Limited.

${ }^{\mathrm{k} B a i l l i e, ~ B R . ~(1999) . ~ M a n a g e m e n t ~ o f ~ l o g g i n g ~ s l a s h ~ i n ~}$ streams - results of a survey. (LIRO Project Report PR85). Rotorua, New Zealand: Liro Forestry Solutions.

${ }^{\mathrm{l} D o u g l a s,}$ J, Stokes, S, Waiora Soil Conservation. (2011). Report on exotic forest debris management related to storm events in the Bay of Plenty. (Operations Publication 2011/03 for the Bay of Plenty Regional Council). Whakatane, New Zealand: Eastern Bay of Plenty Regional Council.

mPhillips, CJ, Marden, M. (2011). Houpotu Forest storm damage assessment and review. (Landcare Research Contract Report LC777). Lincoln, New Zealand: Landcare Research New Zealand Limited.

${ }^{\mathrm{n}}$ Basher, L. (2010). Storm damage in the Tapawera area during the storm of 16th March 2010. (Landcare Research Internal Report). Lincoln, New Zealand: Landcare Research New Zealand Limited.

${ }^{\circ}$ Page, MJ, Langridge, RM, Stevens, GJ, Jones, KE. (2012). The December 2011 debris flows in the PoharaLigar Bay area, Golden Bay: causes, distribution, future risks and mitigation options. (Geological Science Consultancy Report 2012/305). Wellington, New Zealand: Institute of Geological \& Nuclear Sciences Limited.

${ }^{\mathrm{P}}$ Gray, C, Spencer, M. (2011). Some observations of erosion as a result of the 28 December 2010 storm event. (Technical Report No. 11-024 for the Marlborough District Council). Blenheim, New Zealand: Marlborough District Council.

${ }^{\mathrm{q}}$ Phillips, CJ, Marden, M. (1999). Review of vegetationslope stability in plantation forests and risk assessment of Ohui Forest to landsliding. (Landcare Research Contract Report LC9899/66). Lincoln, New Zealand: Landcare Research New Zealand Limited.

${ }^{\mathrm{r}}$ Marden, M, Rowan, D. (1988). Protective value of different vegetation types in the East Coast Region after Cyclone Bola: a preliminary assessment. (Internal Forest Research Institute Report). Lincoln, New Zealand: Landcare Research New Zealand Limited.

${ }^{\mathrm{s}}$ Coker, R. (1988). Assessment of the Environmental Impacts of Harvesting Whangapoua Forest. (Contract report prepared for NZ Timberlands). Auckland, New Zealand: New Zealand Timberlands Limited.

${ }^{t}$ Williams, M. (1995). Whitianga Storm Event - 4th March 1995. (Environment Waikato Memorandum File 410003). Hamilton, New Zealand. Environment Waikato.

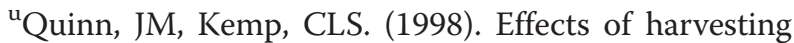
Whangapoua Forest on stream clarity and temperature: 1997 annual report and review of five years monitoring. NIWA Client Report ERN90201/1. Prepared for Ernslaw One Ltd.

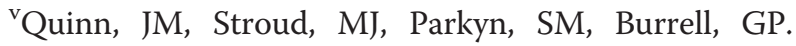
(1995). Impact of an intense rain storm on 3-4 March 1995 on Whangapoua Forest landscape and streams. NIWA Client Report ERN301/1. Prepared for Ernslaw One Ltd.

${ }^{\mathrm{w} W i l d}$ M, Hicks M. (2005). Opitonui Stream suspended sediment analysis. (NIWA Client Report CHC2005-115). Christchurch, New Zealand: National Institute of Water and Atmospheric Research Ltd.

${ }^{\mathrm{x}}$ Morrisey DJ, Burt K, Funnell GA, Hume TM, Kemp CLS, Ovenden R, Smith RK, Swales A. (1999). Ecological monitoring for potential effects of forest activity on the intertidal habitats of Whangapoua Harbour, Annual Report 1998-1999. (NIWA Client Report ERN90202/1). Hamilton, New Zealand. New Zealand: National Institute of Water and Atmospheric Research

${ }^{\mathrm{y}}$ Wright-Stow, AE, Quinn, J M. (2013). Progressive catchment harvesting in Whangapoua Forest: impacts on stream clarity, dissolved oxygen.temperature, habitat and invertebrates: Twenty-first annual report incorporating results from 1992-2013. NIWA Client Report HAM2013-039.

${ }^{\text {z}}$ Phillips, CJ, Marden, M. (1996). Mohaka forest storm damage. (Landcare Research Contract Report LC9596/ 121). Lincoln, New Zealand: Landcare Research New Zealand Limited.

${ }^{\text {aa }}$ Pearce, AJ, O'Loughlin, C. (1976). Effects of forest management on water and soil conservation. (Internal Report to Auckland Conservancy of the New Zealand Forest Service). Auckland, New Zealand: New Zealand Forest Service Limited.

\section{Additional files}

\begin{abstract}
Additional file 1: Description of land use capability units in the study area (National Water and Soil Conservation Organisation, 1975).

Additional file 2: Process-based sediment mass ( $t$ ), percent of total mass and sediment generation rate $\left(\mathrm{t} \mathrm{ha}^{-1}\right)$ by vegetation type. Additional file 3: Process-based sediment mass ( $t$ ), percent of total mass and sediment generation rate $\left(\mathrm{t} \mathrm{ha}^{-1}\right)$ by slope group.

Additional file 4: Process-based sediment mass $(t)$, percent of total mass and sediment generation rate $\left(\mathrm{t} \mathrm{ha}^{-1}\right)$ by land use capability unit. Additional file 5: Process-based sediment mass ( $t$ ), percent of total mass and sediment generation rate $\left(\mathrm{t} \mathrm{ha}^{-1}\right)$ by catchment.
\end{abstract}

Competing interests

The authors declare that they have no competing interests.

Authors' contributions

MM was the primary author, and undertook the stereoscopic analysis, mapping, and interpretation of the data. MM and DR undertook the field 
work, and compiled the data into spreadsheets. Both authors read and approved the manuscript.

\section{Acknowledgements}

This research was supported by funding from the Ministry of Business, Innovation, and Employment, Contract number CO4X1306 Growing Confidence in Forestry to Scion/Future Forest Research. Our thanks go to the staff of Ernslaw One Limited for commissioning the original 1995 contract, for supplying forest compartmental records and aerial photography of the storm-affected area, and latterly for granting permission to publish this work. Environment Waikato (Regional Council) is acknowledged for supplying rainfall, and flow data. Thanks to Drs Les Basher, Chris Phillips and two external reviewers for their helpful comments, and suggestion. Figures were drawn by Nicolette Faville, and Anne Sutherland. Anne Austin edited the script. Suggested improvements by the journal's Associate editor and Editor-in-chief are much appreciated.

\section{Author details}

'Landcare Research, PO Box 445, Gisborne 4010, New Zealand. ${ }^{2} 16$ Elgin

Place, Whangarei 0112, New Zealand.

Received: 1 August 2014 Accepted: 16 March 2015

Published online: 24 June 2015

\section{References}

Basher, LR, Hicks, DM, Clapp, B, \& Hewitt, T. (2011). Sediment yield responses to forest harvesting and large storm events, Motueka River, New Zealand. New Zealand Journal of Marine and Freshwater Research, 45, 333-356.

Bergin, DR, Kimberley, MO, \& Marden, M. (1995). Protective value of regenerating tea-tree stands on erosion-prone hill country, East Coast, North Island, New Zealand. New Zealand Journal of Forest Science, 25, 3-19.

Beverley, CW, Swanson, FJ, \& Jones, JA. (2001). Forest roads and geomorphic process interactions, Cascade Range, Oregon. Earth Surface Processes and Landforms, 26, 191-204.

Bishop, DM, \& Stevens, ME. (1964). Landslide on logged areas in south-eastern Alaska. (Paper NOR-1).Juneau, AL, USA: Northern Forest Experiment Station, Forest Service, U.S. Dept. of Agriculture.

Blaschke, PM, Trustrum, NA, \& DeRose, RC. (1991). Ecosystem processes and sustainable land use in New Zealand steep lands. Agriculture Ecosystems and Environment, 41, 153-178

Caine, N. (1980). Rainfall intensity-duration control of shallow landslide and debris flows. Geografiska Annaler, 62A(1-2), 23-29.

Chudleigh, PD, Greer, G. \& Sheppard, RL. (1983). Supporting the Agricultural Sector: Rationale and Policy. Agricultural Economics Research Unit, Lincoln College, New Zealand. ISSN 0110-7720

Committee of Inquiry. (1939). Maintenance of vegetative cover in New Zealand, with special reference to land erosion. (DSIR Bulletin 77). Wellington, New Zealand: DSIR.

Coulter, JD, \& Hessell, JWD. (1980). The frequency of high intensity rainfalls in New Zealand. Part III. Point estimates. (New Zealand Meteorological Service Miscellaneous Publication 162). Wellington, New Zealand: New Zealand Meteorological Service.

Crozier, MJ, \& Eyles, RJ. (1980). Assessing the probability of rapid mass movement. Third Australia-New Zealand Conference on Geomechanics, (Vol 2, pp. 2.47-2.53). Wellington, New Zealand: Institute of Engineers Proceedings of Technical Groups.

Cunningham, A, \& Stribling, PW. (1978). The Ruahine Range - A Situation Review and Proposals for Integrated Management of the Ruahine Range and the Rivers Affected By It. Water and Soil Technical Publication, 13

Dymond, JR, Ausseil, AG, Shepherd, JD, \& Buettner, L. (2006). Validation of a region-wide model of landslide susceptibility in the Manawatu-Wanganu region of New Zealand. Geomorphology, 74, 70-79.

Esler, AE. (1963). The Influence of the Pre-European Fires in the Tiritea Catchment, Northern Tararuas. Proceedings of the New Zealand Ecological Society, $10,8-12$.

Eyles, GO. (1985). The New Zealand Land Resource Inventory Erosion Classification. (Water and Soil Miscellaneous Publication 85). Wellington, New Zealand: National Water and Soil Conservation Authority.

Fahey, BD, \& Coker, RJ. (1989). Forest road erosion in the granite terrain of southwest Nelson, New Zealand. Journal of Hydrology (NZ), 28(2), 123-141.

Fahey, BD, \& Coker, RJ. (1992). Sediment production from forest roads in Queen Charlotte Forest and potential impact on marine water quality, Marlborough
Sounds, New Zealand. New Zealand Journal of Marine and Freshwater Research, 26, 187-195.

Fahey, BD, \& Marden, M. (2000). Sediment yields from a forested and a pasture catchment, coastal Hawke's Bay, North Island, New Zealand. Journal of Hydrology (NZ), 39(1), 49-63.

Fahey, BD, Marden, M, \& Phillips, CJ. (2003). Sediment yields from plantation forestry and pastoral farming, coastal Hawke's Bay, North Island, New Zealand. Journal of Hydrology (NZ), 42(1), 27-38.

Fahey, B, Duncan, M, \& Quinn, J. (2004). Impacts of Forestry. In J Harding, P Mosley, C Pearson, \& B Sorrell (Eds.), Freshwaters of New Zealand (Chapter 33). Christchurch, New Zealand: Institute of Engineers Proceedings of Technical Groups.

Fannin, RJ, Moore, GD, Schwab, JW, \& VanDine, DF. (2005). Landslide risk management in forest practices. In: Proceedings International Conference on Landslide Risk Management (pp. 299-320), Vancouver, B.C., Canada, 31 May-June 3.

Fransen, PJB, \& Brownlie, RK. (1995). Historical slip erosion in catchments under pasture and radiata pine forest, Hawke's Bay hill country. New Zealand Forestry, 40(4), 29-33.

Furbish, DJ, \& Rice, RM. (1983). Predicting landslide related to clearcut logging, North-western California. U. S. A. Mountain Research and Development, 3(3), 253-259.

Glade, T. (1998). Establishing the frequency and magnitude of landslide triggering rainstorm events in New Zealand. Environmental Geology, $35,160-174$

Glade, T, \& Crozier, MJ. (1996). Towards a national landslide information base for New Zealand. New Zealand Geographer, 52(1), 29-40.

Grant, PJ. (1977). Recorded Channel Changes of the Upper Waipawa River, Ruahine Range, New Zealand. Water \& Soil Technical Publication, 6. Wellington, NZ: Ministry of Works and Development.

Guthrie, RH. (2002). The effects of logging on frequency and distribution of landslide in three watersheds on Vancouver Island, British Columbia. Geomorphology, 43, 273-292.

Harmsworth, GR, Hope, GD, Page, MJ, \& Manson, PA. (1987). An assessment of storm damage at Otoi in Northern Hawkes Bay. (Publication 10).Palmerston North, New Zealand: Soil Conservation Centre.

Hewitt, AE. (2010). New Zealand Soil Classification. (Landcare Research Science Series 1 (3rd ed.). Lincoln, New Zealand: Manaaki Whenua Press.

Hicks, DL. (1989). Storm damage to bush, pasture and forest during Cyclone Bola. (Technical Report PN2). Palmerston North, New Zealand: DSIR Soil Conservation Centre.

Hicks, DL. (1991). Erosion under pasture, pine plantations, scrub and indigenous forest: a comparison from Cyclone Bola. New Zealand Forestry, 36(3), 21-22.

Hicks, DM, \& Basher, LR. (2008). The signature of an extreme erosion event on suspended sediment loads: Motueka River Catchment, South Island, New Zealand. Sediment Dynamics in Changing Environments. In: Proceedings of International Association of Hydrological Sciences Symposium (325, 184-191), Christchurch, New Zealand.

High Intensity Rainfall Design System (HIRDS). http://www.niwa.co.nz/software/ hirds. Accessed 05.08.2014

Holdaway, RJ, Easdale, TA, Mason, NWH, \& Carswell, FE. (2013). LUCAS National Forest Plot Analysis: Are New Zealand's Natural Forests a Source or Sink of Carbon? Wellington, New Zealand: Ministry for the Environment.

Horner, M. (2012). After the storms-a case study in risk reduction. New Zealand Journal of Forestry, 56(4), 13-15.

Howes, DE. (1987).A method for predicting terrain susceptibility to landslide following forest harvesting: a case study from the southern Coast Mountains, British Columbia. Forest Hydrology and Watershed Management. In: Proceedings of the International Association of Hydrological Sciences Symposium, (pp. 143-154). XIX General Assembly of the International Union of Geodesy and Geophysics, August 12-22, University of British Columbia, Vancouver.

IPCC (2014). Summary for policymakers. In: Climate Change 2014: Impacts, Adaptation, and Vulnerability. Part A: Global and Sectoral Aspects. Contribution of Working Group II to the Fifth Assessment Report of the Intergovernmental Panel on Climate Change [Field, CB. VR. Barros, DJ. Dokken, KJ. Mach, MD. Mastrandrea, TE. Bilir, M. Chatterjee, KL. Ebi, YO. Estrada, RC. Genova, B. Girma, ES. Kissel, AN. Levy, S. MacCracken, PR. Mastrandrea, and LL. White (Eds.)]. Cambridge University Press, Cambridge, United Kingdom and New York, NY, USA, pp. 1-32.

Jakob, M. (2000). The impacts of logging on landslide activity at Clayoquot Sound, British Columbia. Catena, 38, 279-300. 
James, IL. (1973). Mass Movement in the Upper Pohangina Catchment, Ruahine Range. New Zealand Journal of Hydrology, 12, 92-102.

Marden, M. (2004). Future-proofing erosion-prone hill country against soil degradation and loss during large storm events: have past lessons been heeded? New Zealand Journal of Forestry, 49, 11-16.

Marden, M. (2012). Effectiveness of reforestation in erosion mitigation and implications for future sediment yields, East Coast catchments, New Zealand: A review. New Zealand Geographer, 68, 24-35.

Marden, M, \& Rowan, D. (1993). Protective value of vegetation on tertiary terrain before and during Cyclone Bola, East Coast, North Island, New Zealand. New Zealand Journal of Forest Science, 23(3), 255-263.

Marden, M, \& Saunders, H. (1992). Balancing forestry economics and stewardship of the East Coast environment. Conservation Quorum (Gisborne District Council), 8, 8-9.

Marden, M, Phillips, CJ, \& Rowan, D. (1991). Declining soil loss with increasing age of plantation forests in Uawa catchment, East Coast region, North Island, New Zealand. In Proceedings, International Symposium on Sustainable Land Management, (pp. 358-361) (pp. 18-23). New Zealand: Napier.

Marden, M, Rowan, D, \& Phillips, C. (2006). Sediment sources and delivery following plantation harvesting in a weathered volcanic terrain, Coromande Peninsula, North Island, New Zealand. Australian Journal of Soil Research, 44, 219-232.

Marden, M, Rowe, L, \& Rowan, D. (2007). Slope wash erosion following plantation harvesting in pumice terrain and its contribution to stream sedimentation, Pokairoa catchment, North Island, New Zealand. Journal of Hydrology, 46, 73-90.

Marden, M, Basher, L, Phillips, C, \& Black, R. (2015). Should detailed terrain stability or erosion susceptibility mapping be mandatory in erodible steep lands? New Zealand Journal of Forestry, 59(4), 42-52.

McCraw, JD, \& Bell, JL. (1975). Soils of the Coromandel-Thames Counties. In Land Inventory Survey of Coromandel-Thames Counties. Department of Lands and Survey. 88 p, 6 maps.

McKelvey, P. (1992). The development of the concept of steep land protection forestry in New Zealand. New Zealand Forestry, 20-24.

McLaren, P. (1993). Radiata Pine Growers Manual. Forest Research Institute Bulletin 184, New Zealand Forest Research Institute Limited, Rotorua, New Zealand. $134 \mathrm{p}$.

Megahan, WF, Monsen, SB, \& Wilson, MD. (1991). Probability of sediment yields from surface erosion on granite road fills in Idaho. Journal of Environmental Quality, 20(1), 53-60.

Megahan, WF, Wilson, M, \& Monsen, SB. (2001). Sediment production from granitic cutslopes on forest roads in Idaho, USA. Earth Surfaces Processes and Landforms, 26, 153-163.

Millard, T. (1999). Debris flow initiation in Coastal British Columbia gullies. (Forest Research Technical Report). Nanaimo, British Columbia, Canada: British Columbia Ministry of Forests, Vancouver Forest Region.

Mosley, MP. (1980). The impact of forest road erosion in the Dart Valley, Nelson, New Zealand. New Zealand Journal of Forestry, 23, 184-198.

National Water and Soil Conservation Organisation. (1975). New Zealand Land Resource Inventory Worksheets. Wellington, New Zealand: New Zealand Government Printer

O'Loughlin, CL. (1972). A preliminary study of landslide in the coast mountains of southwestern British Columbia. In S HO \& MP HJ (Eds.), Mountain Geomorphology, Geomorphological Processes in the Canadian Cordillera. (B. C. Geographical Series Vol. 14, pp. 101-111). Vancouver, British Columbia, Canada: Tantalus Research.

O'Loughlin, CL. (1985). Influences of exotic plantation forest on slope stability implications for exotic forest management in the Marlborough Sounds. In Proceedings of the Soil Dynamics and Land-Use Seminar, Blenheim.

O'Loughlin, CL, \& Ziemer, RR. (1982). The importance of root strength and deterioration rates upon edaphic stability in steep land forests. In RH Waring (Ed.), Carbon uptake and allocation in subalpine ecosystems as a key to management. Corvallis: Proceedings of IUFRO Workshop.

O'Loughlin, CL, Rowe, LK, Pearce, AJ. (1982). Exceptional storm influences on slope erosion and sediment yields in small forest catchments, north Westland, New Zealand. In: EM, O'Loughlin, EJ, Bren (Eds.). Institute of Engineers, Australian National Conference publication, 82/6, 152 p.

Olsen, PF. (1970). Mangatu: A production forest with major protection value. New Zealand Journal of Forestry, 15(2), 169-183.

Pearce, AJ. (1977). Landscape zoning, erosion control and forest management. What's New in Forest Research? 55. Wellington, New Zealand: Forest Research Institute.
Pearce, AJ, \& Hodgkiss, PD. (1987). Erosion and sediment yield from a landing failure after a moderate rainstorm, Tairua Forest. New Zealand Journal of Forestry, 32(2), 19-22.

Phillips, CJ, \& Marden, M. (2005). Reforestation schemes to manage regional landslide risk. In T, Glade, MG, Anderson, MJ, Crozier. (Eds.). Landslide Hazard and Risk. (pp. 731-752). Chichester, UK: John Wiley and Sons Ltd.

Phillips, CJ, Marden, M, \& Rowan, D. (1989). Planning for forestry after Cyclone Bola: a comment. New Zealand Forestry, 16-17.

Phillips, CJ, Marden, M, \& Pearce, AJ. (1990). Effectiveness of reforestation in the prevention and control of landsliding during large cyclonic storms. In Proceedings of International Union of Forest Research Organisations XIX World Congress (pp. 340-350), Montreal 1990.

Phillips, CJ, Marden, M, \& Rowan, D. (2005). Sediment yield following plantation harvesting, Coromandel Peninsula, North Island, New Zealand. Journal of Hydrology (NZ), 44, 29-44.

Phillips, C, Marden, M, \& Basher, L. (2012). Plantation forest harvesting and landscape response-what we know and what we need to know. New Zealand Journal of Forestry, 56, 4-12.

Poole, AL. (1960). Protection forests in New Zealand and a Poverty Bay example. New Zealand Geographer, 16(2), 115-130.

Quinn, JM, Cooper, AB, \& Williamson, RB. (1993). Riparian zones as buffer strips: A New Zealand perspective. In Proceedings of a National Workshop on research and management needs for riparian zones in Australia. Held in association with the 32nd Annual Congress of the Australian Society for Limnology, Marcoola, Australia.

Reid, LM, \& Page, MJ. (2002). Magnitude and frequency of landsliding in a large New Zealand catchment. Geomorphology, 49, 71-88.

Rogers, NW, \& Selby, MJ. (1980). Mechanisms of shallow translational landsliding during summer rainstorms, North Island, New Zealand. Geografiska Annaler, $62 A, 11-21$.

Rollerson, TP. (1992). Relationship between landscape attributes and landslide frequencies after logging; Skidegate Plateau, Queen Charlotte Islands (Ministry of Forests Land Management Report 76). British Columbia, Canada: Victoria.

Rollerson, TP, Jones, C, Trainor, K, \& Thomson, B. (1998). Linking post-logging landslide to terrain variables: Coast Mountains, British Columbia-preliminary analyses (In Proceedings of the 8th International Congress of the International Association for Engineering Geology and the Environment, (pp. 1973-1979)). Rotterdam: Balkema.

Rood, KM. (1984). An aerial photograph inventory of the frequency and yield of mass wasting on the Queen Charlotte Islands, British Columbia. (Ministry of Forests Land Management Report 34). Victoria, British Columbia, Canada: Ministry of Forests.

Roy, B, Popay, I, Champion, P, James, T, \& Rahman, A. (1998). An Illustrated Guide to Common Weeds of New Zealand. New Zealand Plant Protection Society (Inc) 282 p. ISBN 0-473-05296-2.

Salter, RT, Crippen, TF, \& Noble, KE. (1983). Storm damage assessment of the Thames-Te Aroha area following the storm of April 1981. (Publication I). Palmerston North, New Zealand: Soil Conservation Centre.

Sauder, EA, Krag, RK, \& Wellburn, GV. (1987). Logging and mass wasting in the Pacific Northwest with application to the Queen Charlotte Islands, B.C. (Land Management Report, 53). Victoria, British Columbia, Canada: British Columbia Ministry of Forests.

Schwab, JW. (1983). Mass wasting: October-November 1978 storm, Rennell Sound, Queen Charlotte Islands, British Columbia. (Ministry of Forests Research Note 91). Victoria, British Columbia, Canada: Ministry of Forests.

Selby, MJ. (1967). Aspects of the geomorphology of the greywacke ranges bordering the lower and middle Waikato basins. Earth Science Journal, 1(1), 37-58.

Service, NZM. (1980). Depth-Duration-Frequency Tables based on daily rainfalls. (New Zealand Meteorological Service Miscellaneous Publication, 162, Supplement 1). Wellington, New Zealand: New Zealand Meteorological Service.

Skinner, DNB. (1976). Geological Map of New Zealand 1:63360 Sheets N40 and part sheets N35, N36 and N39 Northern Coromandel. Wellington, New Zealand: New Zealand Geological Survey.

Smith, RB, Commandeur, PR, \& Ryan, MW. (1986). Soils, vegetation, and forest growth on landslide and surrounding logged and old-growth areas on the Queen Charlotte Islands, British Columbia. (Ministry of Forests Land Management Report 41). Victoria, British Columbia Canada: Ministry of Forests.

Taylor, NH. (1938). Land deterioration in the heavier rainfall districts of New Zealand. (DSIR Bulletin 62). Wellington, New Zealand: DSIR. 
Taylor, NH (Ed.). (1970). Wise land use \& community development, report of Technical Committee of Inquiry into the problems of the Poverty Bay-East Cape District of New Zealand. Wellington. Wellington, New Zealand: Water and Soil Division, Ministry of Works for the National Water and Soil Conservation Organisation.

Thomson, B. (1987). Chapman Creek landslide inventory (1:20,000 scale map with legend). Victoria, British Columbia, Canada: British Columbia Ministry of Environment, Lands and Parks.

Wardle, P. (1991). Vegetation of New Zealand. ISBN: 1-930665-58-X. The Blackwell Press, USA. 672 p.

Watson, AJ. (1990). Contribution of tree roots to slope stability. What's New in Forest Research 196. Wellington, New Zealand: Forest Research Institute.

Watson, A, Marden, M, \& Rowan, D. (1995). Tree species performance and slope stability. In: DH, Barker. (Ed.) Vegetation and Slopes, stabilization, protection and ecology. (pp. 161-171). London, UK: Thomas Telford.

Watson, A, Phillips, C, \& Marden, M. (1999). Root strength, growth, and rates of decay: root reinforcement changes of the two species and their contribution to slope stability. Plant and Soil, 217, 39-47.

Ziemer, RR. (1981a). Roots and the stability of forested slopes. In Proceedings of the International Symposium on Erosion and Sediment Transport in Pacific Rim Steep lands. (pp. 343-361). (International Association of Hydrological Sciences Publication 132). Christchurch, New Zealand: International Association of Hydrological Sciences.

Ziemer, RR. (1981b).The role of vegetation in the stability of forested slopes. In Proceedings of the International Union of Forestry Research Organisations XVII World Forestry Congress, (pp. 297-308). Kyoto, Japan.

Ziemer, RR. (1981c). Management of steep land erosion: An overview. Keynote address, Theme 4. Journal of Hydrology (NZ), 20, 8-16.

\section{Submit your manuscript to a SpringerOpen ${ }^{\circ}$ journal and benefit from:}

- Convenient online submission

- Rigorous peer review

- Immediate publication on acceptance

- Open access: articles freely available online

- High visibility within the field

- Retaining the copyright to your article

Submit your next manuscript at $>$ springeropen.com 